Przegląd Prawa Konstytucyjnego

----ISSN 2082-1212-----

DOI 10.15804/ppk.2018.02.11

-----Nr $2(42) / 2018-----$

\title{
Recenzja
}

\section{Marcin M. Wiszowaty, Zasada monarchiczna i jej przejawy we współczesnych ustrojach europejskich i pozaeuropejskich monarchii mieszanych, ISBN 978-83-7865-289-2, Wydawnictwo Uniwersytetu Gdańskiego, Gdańsk 2016, ss. 592}

Temat ustroju współczesnych monarchii, ze szczególnym uwzględnieniem przejawów monarchiczności w tychże państwach, wydaje się zagadnieniem archaicznym, zdezaktualizowanym, statycznym i - tym samym - mało interesującym z poznawczego punktu widzenia. Wydaje się taki przed lekturą książki Marcina M. Wiszowatego pt. Zasada monarchiczna i jej przejawy we współczesnych ustrojach europejskich i pozaeuropejskich monarchii mieszanych.

Monografia jest dziełem oryginalnym i unikatowym głównie dlatego, że po raz pierwszy w polskiej literaturze naukowej z dziedziny prawa konstytucyjnego przeprowadzono badania, którymi objęto wszystkie współczesne monarchie, zarówno europejskie jak i pozaeuropejskie. Dogłębnej analizie poddano ustroje 33 państw świata: dziewięć monarchii europejskich (Andorę, Belgię, Danię, Hiszpanię, Niderlandy, Liechtenstein, Luksemburg, Monako, Norwegię, Zjednoczone Królestwo Wielkie Brytanii i Irlandii Północnej) oraz jedną europejską republikę monarchiczną (Szwecję), piętnaście państw Wspólnoty Narodów, które uznają Elżbietę II za monarchę (Antigua i Barbudę, Australię, Bahamy, Barbados, Belize, Grenadę, Jamajkę, Kanadę, Nową Zelandię, Papua-Nowa Gwinea, Saint Kitts i Nevis Lesotho, Saint Lu- 
cia, Saint Vincent i Grenadyny Suazi, Tuvalu i Wyspy Salomona), pięć monarchii arabskich (Bahrain, Jordania, Katar, Kuwejt, Maroko), dwie monarchie buddyjskie (Bhutan i Tajlandię) i polinezyjskie Królestwo Tonga (s. 22). Między innymi z tego względu Marcin Wiszowaty za recenzowaną pozycję otrzymał drugie miejsce w konkursie miesięcznika „Państwo i Prawo” na najlepsze prace habilitacyjne oraz został nominowany w prestiżowym Konkursie o Nagrodę im. Jana Długosza. Jego celem jest nagrodzenie dzieła o wybitnych wartościach poznawczo-naukowych z dziedziny szeroko rozumianej humanistyki. Autor monografii jest doktorem habilitowanym i profesorem Uniwersytetu Gdańskiego.

Niewątpliwą zaletą pozycji jest dogłębna analiza piśmiennictwa, która tworzy imponujące ramy teoretyczno-historyczne dla opracowania. Autor swobodnie prezentuje stosowane w nauce typologie i klasyfikacje monarchii, wskazując przy tym na panujący w literaturze chaos i brak konsekwencji. Przykładowo, podział monarchii na cesarstwa, królestwa, wielkie księstwa i księstwa ma walor wyłącznie historyczny. Z kolei rozróżnienie monarchii na średniowieczne monarchie feudalne (patrymonialne i stanowe), monarchie absolutne i monarchie konstytucyjne i parlamentarne uwzględnia jedynie kryterium chronologiczne i stwarza nikłe możliwości analityczne. Autor przywołuje też podział monarchii na dziedziczne i elekcyjne, z tym że tych drugich w ogóle nie uznaje za monarchie, ponieważ nie spełniają jednego z podstawowych założeń zasady monarchiczności, tj. dziedziczności tronu. Dużo przychylniej Autor traktuje podział monarchii na pełne (czyste, autokratyczne) i mieszane (tzw. monarchia mixta). W monarchiach czystych władca jest jedynym podmiotem władzy, w mieszanych dzieli się nią na ogół ze społeczeństwem reprezentowanym przez organy lub stany społeczne (s. 40-42). Interesująca wydaje się polemika Autora z Arturem Ławniczakiem. Otóż wspomniany prawnik stoi na stanowisku, że monarchie przymiotnikowe, tj. konstytucyjna, parlamentarna, czy demokratyczna to oksymorony, ponieważ w takich ustrojach władza jest dzielona między różne ośrodki, co jest niezgodne z definicją monarchii ${ }^{1}$. Marcin Wiszowaty jest odmiennego zdania, twierdząc, że nazw form państwa nie należy traktować dosłownie. Na poparcie tej tezy przytacza przykład słowa „demokracja”, które to jako forma państwa nie jest i ni-

1 A. Ławniczak, Monarchiczne i republikańskie głowy państwa w Europie, Wrocław 2011, s. 65. 
gdy nie była „rządami ludu” jak jej nazwa wskazuje. Podobnie warunkiem koniecznym zakwalifikowania ustroju jako monarchiczny nie jest fakt sprawowania pełni władzy przez jedną osobę. Określenia monarchii służą opisaniu jej odmian (s. 43). Autor przywołuje wiele typologii monarchii zarówno z polskiej jak i zagranicznej literatury i dowodzi, że nie istnieje jedno ustalone rozumienie pojęć „monarchia absolutna”, „konstytucyjna” i „parlamentarna" oraz ich wzajemnych relacji, ponieważ metodologia tego podziału opiera się na trzech różnych kryteriach: monarchii absolutnej - na zakresie władzy monarchy, monarchii parlamentarnej - na formie rządów, monarchii konstytucyjnej - na istnieniu w systemie źródeł prawa konstytucji pisanej (s. 77).

Kreśląc taką sytuację w piśmiennictwie z dziedziny prawa konstytucyjnego Autor proponuje nową typologię monarchii, którą opiera na dwóch założeniach: po pierwsze, wśród współczesnych monarchii na świecie istnieją w przeważającej mierze monarchie mieszane, po drugie, wprowadzić należy nowe kryterium podziału monarchii: stopień realizacji w ich ustroju tzw. zasady monarchicznej. Monarchia mieszana to ustrój, który łączy w sobie elementy republikańskie i monarchiczne. Natomiast zasada monarchiczna wywodzi się z konstytucjonalizmu niemieckiego i wciąż występuje w ustrojach współczesnych monarchii mieszanych, ale została zaktualizowana o zasadę suwerenności narodu i podziału władzy. Współczesna zasada monarchiczna polega na występowaniu w ustroju państwa dziedzicznego i monokratycznego organu monarchy, który cechuje się: brakiem kadencyjności, posiadaniem realnego udziału we władzy, autonomią względem aktualnego układu sił politycznych, pozawyborczą legitymizacją uprawnień władczych oraz brakiem odpowiedzialności. Ponadto, zasada monarchiczna przejawia się w istnieniu innych typowo monarchicznych instytucji, np. rodziny królewskiej, regenta, dworu królewskiego (s. 78-81). Klasyfikacja Marcina Wiszowatego obejmuje cztery kategorie ustrojowe: (a) monarchię czystą (pełną, autorytarną), w której nie występują elementy republikańskie; (b) czystą republikę, w której nie ma elementów zasady monarchicznej; (c) monarchię królewską, w której realizacja zasady monarchicznej występuje w znacznym stopniu, tj. król pełni większość funkcji monarszych, a w ustroju funkcjonuje większość instytucji monarchicznych; (d) monarchię republikańską, w której przymiot suwerenności należy do narodu, co gwarantuje konstytucja, a skala realizacji zasady monarchicznej ma charakter ograniczony: większość tradycyjnych instytu- 
cji monarszych uległa likwidacji, władzę ustawodawczą sprawują parlament i rząd, a wykonywanie kompetencji przez króla wymaga każdorazowo kontrasygnaty członka gabinetu (s. 82-87). Niewątpliwą zaletą książki jest wzbogacenie opisanej klasyfikacji o przykłady zarówno współczesne jak i historyczne. Autor - mimo deklaracji, że analiza historyczna nie jest jego celem - sprawnie i bardzo konkretnie operuje egzemplifikacjami z różnych krajów, choć głównie europejskich.

Monografia Marcina Wiszowatego to także wnikliwa analiza instytucji monarchy we współczesnych monarchiach mieszanych, tj. królewskich i republikańskich. Jedną z tez pracy jest wykluczenie monarchii elekcyjnych z grona monarchii i uznanie ich za republiki monarchiczne. Dotyczy to państw takich jak Watykan, Malezja i Kambodża. Autor słusznie uzasadnia, że wyznacznikiem monarchiczności jest dziedziczny i dożywotni status króla. Elekcyjność władzy pozbawia ustrój państwa większości istotnych cech monarchicznych, np. instytucji następcy tronu i instytucji dynastii. W efekcie eliminacji ulega jeden z czynników zapewniający ciągłość państwa i władzy oraz będący symbolem narodu. Upolitycznienie głowy państwa osłabia jego rolę jako reprezentanta całego narodu i uzależnia go od elektorów (s. 92).

Marcin Wiszowaty systematyzuje kompetencje monarchy, grupując je w cztery kategorie: król jako władca, reprezentant narodu, strażnik konstytucji i podmiot praw i wolności człowieka. Bezdyskusyjnym atutem pracy, który czyni ją też dziełem unikatowym w polskim piśmiennictwie dyscypliny jest przeanalizowanie uprawnień i obowiązków monarchy w ramach każdej z kategorii w oparciu zarówno o regulacje prawne jak i praktykę ustrojową. Badanie uprawnień króla wyłącznie przez pryzmat jego kompetencji w zestawieniu z innymi organami państwa na podstawie aktów normatywnych (przeważnie konstytucji) i wyrokowanie na tej podstawie o znikomej roli króla we współczesnych monarchiach jest - zdaniem Autora - zabiegiem błędnym (s. 179).

W tym miejscu na szczególną uwagę zasługuje metodologia pracy. Oprócz typowych dla badań prawnoporównawczych metod formalno-dogmatycznej, historyczno-opisowej i logicznej, Marcin Wiszowaty zastosował w swojej monografii także metodę analizy funkcjonalnej i metodę kontekstową. Celem takiego zabiegu metodologicznego było ukazanie wybranych praktycznych aspektów ustroju państw monarchicznych. Zdaniem Autora właściwa interpretacja przepisów prawnych wymaga sięgania do płaszczyzny politycznej. 
Zastosowanie metody analizy funkcjonalnej pozwoliło wzbogacić bibliografię opracowania o zagraniczne materiały prasowe. Po lekturze książki wydaje się to szczególnie cenne w odniesieniu do praktyki ustrojowej monarchii buddyjskich i arabskich. Zastosowana metodologia zbliża też monografię do nauk politycznych.

Wartością dodaną pozycji jest też jej fragment poświęcony prawu sankcji ustawodawczej. Jest to ekskluzywna instytucja monarchicznego prawa konstytucyjnego. Polega na zatwierdzaniu i nadaniu mocy prawnej projektowi ustawy. W monarchii mieszanej przetworzenie projektu ustawy w ustawę następuje w drodze zaakceptowania przez monarchę propozycji legislacyjnej przedstawionej przez parlament. Idea tej instytucji polega na tym, że to monarcha decyduje, czy projekt ustawodawczy stanie się obowiązującym prawem. Przy podejmowaniu tej decyzji nie jest zobligowany do uwzględniania woli parlamentu czy jakiegokolwiek innego organu. Jest to więc instytucja, która zapewnia monarsze realny wpływ na prawodawstwo ${ }^{2}$. Autor odróżnia prawo sankcji od prawa weta i promulgacji, podając przykłady państw, w których występują powyższe instytucje. Prawo sankcji przysługuje monarchom brytyjskim, norweskim, duńskim i niderlandzkim. Istotny w prawie sankcji jest fakt, że w większości akty króla podlegają kontrasygnacie rządu, ale w praktyce często odbywa się to w odwrotnej kolejności - akt królewski najpierw jest podpisywany przez właściwego członka rządu, a dopiero później przez monarchę. Autor zwraca uwagę, że wprawdzie król rzadko decyduje się na odmowę podpisania aktu, ale nie jest prawdą, że prawo sankcji stało się instytucją martwą. Na poparcie tej tezy Marcin Wiszowaty przytacza najświeższe przykłady użycia prawa sankcji a także kreśli historię tej instytucji w wybranych monarchiach europejskich. Stawiając taką tezę, Autor stoi w opozycji do poglądów większości reprezentantów dyscypliny, którzy to utrzymują, że prawo sankcji we współczesnych monarchiach zanikło lub przynajmniej zanika (s. 196-223).

Wśród uprawnień władczych monarchy na większą uwagę zasługuje jeszcze - zaliczane do reliktów władzy monarszej - prawo króla do bicia monety. Naturalną konsekwencją tego prawa jest fakt, że monety państw monarchicz-

2 Szerzej: J.Zaleśny, Partycypacja głowy państwa w ostatnich etapach procesu legislacyjnego, Warszawa 1999. 
nych przedstawiają wizerunek króla. Sytuacja staje się bardziej interesująca w przypadku monarchii należących do strefy euro. Tradycyjne prawo do bicia monety w przypadku tych państw obejmuje także monety euro. Monety euro mają stronę wspólną (europejską) i stronę narodową. Strona narodowa wskazuje na kraj emisji. Przykładowo, belgijskie monety euro na stronie narodowej przedstawiają wizerunek króla Alberta II i Filipa, a monety hiszpańskie m.in. portrety króla Jana Karola I ${ }^{3}$. Jednak - jak słusznie zauważa Marcin Wiszowaty - rangę tego symbolicznego uprawnienia obniża fakt, że w obiegu na terenie państw strefy euro (w tym monarchii) występują monety ze wszystkich państw strefy euro (w tym nie monarchii) (s. 235).

Marcin Wiszowaty w swojej monografii porusza też bardzo ciekawy wątek często pomijany w analizach ustrojowych monarchii, a mianowicie - inne niż monarcha instytucje monarchiczne. Wśród instytucji tych Autor wyróżnia: dziedziczne organy władzy publicznej (dziedziczni członkowie parlamentu), monarchiczne organy kadencyjne i dożywotnie (nieelekcyjne izby parlamentu, rady królewskie, organy heraldyczne i nobilitacyjne, inne urzędy i funkcje: np. dwór monarszy, gubernatorzy), szlachtę, dynastię i rodzinę królewską (następcę tronu, małżonka króla), instytucję regencji i zastępstwa monarchy, a także pozostałe instytucje monarchiczne, które można jeszcze odnaleźć tylko w niektórych państwach jak na przykład referendum monarchiczne w Liechtensteinie.

Spośród wskazanych instytucji najciekawsza wydaje się rodzina królewska. Chyba najwięcej kontrowersji, a tym samym argumentów dla przeciwników monarchii, dostarcza kwestia wysokich kosztów utrzymania rodziny królewskiej z podatków poddanych. Autor monografii przytacza interesujące badania, z których wynika, że porównanie kosztów, jakie są ponoszone z budżetów państw monarchicznych i republikańskich na utrzymanie głów państw i ich otoczenia wypada na korzyść monarchii. Powołuje się m.in. na argument dodatkowych wydatków republik wynikających z sekwencyjnej, stosunkowo częstej zmiany na stanowisku prezydenta oraz zyski, jaki przynosi Skarbowi Państwa monarchia, stanowiąca atrakcję turystyczną (s. 394).

3 Europejski Bank Centralny, https://www.ecb.europa.eu/euro/coins/html/es.pl.html (5.09.2017). 
Najbardziej nowatorska część pracy dotyczy analizy ustrojów monarchicznych państw pozaeuropejskich. Marcin Wiszowaty w celu przeprowadzenia tego badania stworzył unikatowe narzędzie, tzw. „test monarchiczności”. Test to zestaw kryteriów badawczych, które zostały zastosowanie do analizy ustrojów współczesnych monarchii pozaeuropejskich i umożliwiły ich zakwalifikowanie do grona monarchii mieszanych lub wykluczenie ich z tej grupy a także przyporządkowanie tych państw do jednej z kategorii w autorskiej typologii Marcina Wiszowatego, tj. monarchie królewskie lub monarchie republikańskie. Test monarchiczności został wypracowany na podstawie badań ustrojów europejskich, a następnie poddany weryfikacji w oparciu o badania monarchii pozaeuropejskich, ponieważ Autor z powodzeniem broni tezy, zgodnie z którą, idea monarchii mieszanej ma europejski rodowód. Twierdzeniu temu można byłoby zarzucić europocentryzm, jednak Autor przytacza przekonujące argumenty, które dowodzą, że brytyjskie rozwiązania ustrojowe wpłynęły na ustroje wszystkich pozaeuropejskich państw monarchicznych. Pozaeuropejskie monarchie mieszane zostały podzielone na trzy grupy: monarchie arabskie, monarchie buddyjskie i pozostałe monarchie pozaeuropejskie (s. 433).

Oryginalność monografii Marcina Wiszowatego polega również na tym, że nie poprzestał na wyliczeniu państw, które - jego zdaniem - należą do grona państw monarchicznych, ale szczegółowo przedstawił kryteria, którymi posługiwał się przy kwalifikacji poszczególnych państw do konkretnej kategorii. Kryteria te funkcjonują w książce pod nazwą testu monarchiczności. Rezultaty testu są dość zaskakujące i stanowią najlepszą zachętę do zapoznania się z blisko 600 -stronicowym dziełem Marcina Wiszowatego. W wyniku testu Autor, szczegółowo to uzasadniając, wykluczył z grona monarchii takie państwa, powszechnie uważane za monarchie, jak: Brunei, Japonia, Kambodża i Malezja, Suazi, Lesotho i Szwecja.

Na zakończenie warto wspomnieć, że Marcin Wiszowaty należy do entuzjastów monarchii i nie ukrywa tego w recenzowanej monografii. Pogłoski o rychłym upadku monarchii są - zdaniem Autora - przesadzone. Na poparcie tej tezy przytacza badania statystyczne z 2013 r., z których wynika, że liczba zwolenników monarchii (nie tylko europejskich) przewyższa ich przeciwników. Autor pozytywnie ocenia metamorfozę, jaką przeszło wiele monarchii, odchodząc od rządów opartych na strachu i stając się szanowanym symbolem narodowej jedności. Marcin Wiszowaty, wykorzystując funk- 
cję prognostyczną pracy, wskazuje na kilka grup czynników, które właściwie wykorzystane mogą przyczynić się do umocnienia roli królów we współczesnym świecie. Do czynników tych zalicza: (a) zagrożenie dezintegracją państwa zauważalne w Belgii, Hiszpanii i Tajlandii (b) zagrożenie utraty tożsamości ze względu na bliskie związki geograficzne i kulturowe z większymi państwami, np. w Luksemburgu czy Bhutanie (c) zjawisko rozproszonych rządów wielopartyjnych, w których król jest bezstronnym elementem systemu, np. w Norwegii, Danii i Niderlandach (d) zagrożenie utraty tożsamości ze względu na wzrost napływu emigrantów do wielu zamożnych monarchii oraz (e) sprawne zarządzanie deficytowymi dobrami, jak złoża bogactw naturalnych co jest praktyką monarchii arabskich (s. 532-541).

Podsumowując, jak starałam się wykazać, monografia Marcina Wiszowatego jest dziełem oryginalnym i unikatowym. W interesujący sposób wypełnia lukę w polskim piśmiennictwie dziedziny, w którym nie odnajdujemy równie kompleksowego opracowania aspektów monarchicznych we wszystkich współczesnych monarchiach świata. Ponadto, jak przystało na rozprawę habilitacyjną, imponuje warsztatem naukowym i adekwatnością zastosowanych metod badawczych. Z tego względu myślę, że jest lekturą godną polecenia nie tylko dla badaczy zajmujących się tematyką współczesnych systemów politycznych, ale też wszystkich politologów, prawników i europeistów, którzy szukają inspiracji metodologicznych.

Martyna Karwowska-Zając Uniwersytet Warszawski 